\title{
20. AMINO ACID CONTENT OF SOME SAMPLES FROM THE DEEP SEA DRILLING PROGRAM
}

\author{
John F. Wehmiller, Lamont-Doherty Geological Observatory, Palisades, New York; and \\ Geophysical Laboratory, Carnegie Institution of Washington, Washington, D. C. \\ and \\ P. E. Hare, Geophysical Laboratory, Carnegie Institution of Washington, Washington, D. C.
}

\section{INTRODUCTION}

As part of the overall Organic Geochemistry Program of the Deep Sea Drilling Project, we have determined the amino acid content of several samples from Legs 5 , 6,7 and 9 . Work in this laboratory has been oriented toward an investigation of the relative stability of the various amino acids in geologic environments and their value as indicators of stratigraphic age: samples reported here are interpreted in light of data for younger materials (Hare, 1969; Wehmiller and Hare, 1970).

Analytical techniques have generally been those of Hare (1969); analyses are carried out using the ionexchange technique of Spackman, Stein and Moore (1958). High carbonate samples generally offer little difficulty in extraction and solution of proteinaceous matter. In the case of low carbonate samples, there is some question as to the completeness of extraction. Analyses reported here are tentative only and must be duplicated.

In addition to evaluating the abundance of amino acids in a sample it is useful to determine the extent to which these amino acids can be extracted without acid hydrolysis. Analyses for total amino acids are carried out after hydrolysis in $6 \mathrm{~N} \mathrm{HCl}$ at $110^{\circ} \mathrm{C}$ for 22 hours. Free amino acids are defined as those released by dissolution of carbonate and extraction of the total sample with a slightly $(\sim 1 \mathrm{~N})$ acidic solution. This technique may release some bound amino acids, so it is only a maximum estimate of the free amino acid abundance in a sample.

The quantities of amino acids reported here are quite small and laboratory contamination can obviously be a problem. In order to obtain measurable amounts of amino acids, especially in older samples, large amounts (10 to 20 grams) of material were prepared. The quantities of reagents needed to process these samples do show traces of aspartic acid, threonine, serine, glutamic acid, glycine and alanine. Blank corrections are 10 per cent or less except in the case of serine, where corrections of up to 50 per cent should be made. These have not been done, so that the raw data may be presented.
The low carbonate sediments may contain amino acids which are not extractable by the simple procedure used here. Abelson and Hare (1970) suggest that kerogenlike material can irreversably bind or destroy amino acids, making them unavailable to acid hydrolysis. Destruction of amino acids during acid hydrolysis in the presence of silicate material is also a potential problem (Hare et al., 1970), and the results from one sample (6-47) suggest that this is the case. More rigorous procedures may be necessary in order to understand the amino acid distribution in these lowcarbonate sediments.

\section{RESULTS}

Samples analyzed are summarized in Table 1. Amino acid abundance is given in Table 2. Weights are given as wet weight: heating of Samples $5-36$ and $5-42$ for 6 hours at $110^{\circ} \mathrm{C}$ suggest water contents of $\sim 45$ per cent.

\section{DISCUSSION}

The following parameters are some of those of interest in determining diagenetic reactions and stability relations: the free amino acid/total amino acid ratio, the glycine/alanine and aspartic/glutamic ratios, the alloisoleucine/isoleucine ratio, and the abundance of threonine and serine. D-alloisoleucine is produced by the racemization of L-allo-isoleucine about the $\alpha$ carbon, and on the basis of extrapolation from younger samples (Wehmiller and Hare, 1971), we would expect isoleucine to be racemic (alloiso/iso $\cong 1.3$ ) in samples older than $\sim 12$ million years. This appears to be the case with the samples presented here, except for Sample 5-36, which appears to be too "young" for its absolute age. This can be a consequence of in situ contamination or accidental contamination during laboratory preparation. This is a low carbonate sample and some difficulty was encountered in the desalting procedure, so we do not place too much confidence in the results for this sample.

Sample 5.42 is also a low carbonate sample, but no problems were encountered in its preparation; abundance of amino acids is very low. All other samples are relatively high carbonate ( $>60$ per cent) and agree 
TABLE 1

Samples Analyzed

\begin{tabular}{|c|c|c|c|c|c|c|c|c|}
\hline Leg & Hole & Core & Section & $\begin{array}{l}\text { Sample } \\
\text { Interval }\end{array}$ & Location & $\begin{array}{c}\text { Water } \\
\text { Depth } \\
(\mathrm{m})\end{array}$ & $\begin{array}{c}\text { Organic } \\
\text { Carbon } \\
(\%)\end{array}$ & Age \\
\hline 9 & $82 \mathrm{~A}$ & 3 & 5 & $82-150$ & $\begin{array}{r}02^{\circ} 36^{\prime} \mathrm{N} \\
106^{\circ} 57^{\prime} \mathrm{W}\end{array}$ & 3707 & 0.157 & Pliocene \\
\hline 7 & 62.1 & 12 & 3 & $80-150$ & $\begin{array}{r}01^{\circ} 52.2^{\prime} \mathrm{N} \\
141^{\circ} 56.5^{\prime} \mathrm{E}\end{array}$ & 2591 & 0.41 & $\begin{array}{l}\text { Upper Upper } \\
\text { Miocene }\end{array}$ \\
\hline 7 & 64.1 & 2 & 5 & $72-150$ & $\begin{array}{r}01^{\circ} 44.5^{\prime} \mathrm{S} \\
158^{\circ} 36.5^{\prime} \mathrm{E}\end{array}$ & 2052 & 0.24 & $\begin{array}{l}\text { Lower Middle } \\
\text { Miocene }\end{array}$ \\
\hline 6 & 47.2 & 10 & 5 & $88-180$ & $\begin{array}{r}32^{\circ} 26.9^{\prime} \mathrm{N} \\
157^{\circ} 42.7^{\prime} \mathrm{E}\end{array}$ & 2689 & 0.10 & Lower Paleocene \\
\hline 5 & 42 & 10 & 2 & $89-144$ & $\begin{array}{r}13^{\circ} 50.56^{\prime} \mathrm{N} \\
140^{\circ} 11.31^{\prime} \mathrm{W}\end{array}$ & 4848 & n.a. & Lower Eocene \\
\hline 5 & 36 & 12 & 0 & $0-19$ & $\begin{array}{r}40^{\circ} 59^{\prime} \mathrm{N} \\
130^{\circ} 07^{\prime} \mathrm{W}\end{array}$ & 3272 & 0.25 & Upper Miocene \\
\hline
\end{tabular}

quite well with existing data for foraminifera from deep-sea deposits (Wehmiller and Hare, 1971). Threonine and serine are thermally unstable (Vallentyne, 1964) and would not be expected to be present in the older samples. Their presence provides some index of contamination, though it cannot be too great because of the observed equilibrium ratios of alloisoleucine/ isoleucine. The aspartic/glutamic and glycine/alanine ratios have been found to decrease with age in other samples (Wehmiller and Hare, 1970), and this is the case with these sediments. Aspartic acid, also thermally unstable (Vallentyne, 1964), is stabilized in calcareous matrices. The free amino acid/total amino acid ratio theoretically would approach 1.0 as all amino acids are liberated from peptide bonds; it may never reach a value of 1.0 if amino acids become bound to kerogenlike material (Abelson and Hare, 1970).

In addition to the amino acids reported, several peaks appear in the chromatograms which can only tentatively be identified. Two very large peaks appear in the tyrosine-phenylalanine region in the 5-36 and 5-42 (total) samples. In the case of Sample 5-36, these peaks are each about 20 to 25 per cent of the area of the ammonia peak; they are about 10 per cent in Sample 5 -42. Their identity is unknown. Ornithine, $\alpha$-aminobutyric acid, and $\gamma$-amino-butyric acid are decomposition products of other amino acids (Vallentyne, 1964). Two amines, methyl- and ethyl-amine, appear in the older samples; these elute following ammonia. A peak tentatively identified as ethanolamine is also seen in some samples.

\section{REFERENCES}

Abelson, P. H. and Hare, P. E., 1970. Uptake of amino acids by kerogen. Carnegie Inst. Washington, Yearbook 68. 297.

Hare, P. E., Harada, K. and Fox, S. W., 1970. Analyses for amino acids in lunar fines. Proc. Apollo 11 Lunar Science Conf., Geochim. Cosmochim. Acta. Suppl. 1, 2, 1799.

Hare, P. E. and Mitterer, R. M., 1969. Laboratory simulation of amino acid diagenesis in fossils. Carnegie Inst. Washington, Yearbook 67. 205.

Hare, P. E., 1969. Geochemistry of proteins, peptides, and amino acids. In: Organic Geochemistry, Methods and Results. Eglinton and Murphy (Eds.), New York (Springer-Verlag).

Spackman, D. H., Stein, W. H. and Moore S., 1958. Automatic recording apparatus for use in chromotography of amino acids. Anal. Chem. 30, 1190.

Vallentyne, J. R., 1964. Biogeochemistry of organic matter-II. Geochim. Cosmochim. Acta. 28, 157.

Wehmiller, J. and Hare, P. E., 1970. Amino acid diagenesis in fossil carbonates. Trans. Geol. Soc. Am. 2, (7) (abstract) 718.

, 1971. Racemization of amino acids in marine sediments. Science (in press). 
TABLE 2

Amino Acid Content of Samples (in nanomoles/gm)

\begin{tabular}{|c|c|c|c|c|c|c|c|c|c|c|c|}
\hline AMINO ACID & $\begin{array}{c}\text { 9-82-A } \\
\text { Total }\end{array}$ & $\begin{array}{c}7-62-1 \\
\text { Total }\end{array}$ & $\begin{array}{c}7-64-1 \\
\text { Total }\end{array}$ & $\begin{array}{l}7-64-1 \\
\text { Free }\end{array}$ & $\begin{array}{r}6-47-2 \\
\text { Total }\end{array}$ & $\begin{array}{l}6-47-2 \\
\text { Total }^{\mathrm{a}}\end{array}$ & $\begin{array}{c}6-47-2 \\
\text { Free }\end{array}$ & $\begin{array}{l}6-47-2 \\
\text { Free }^{\mathrm{a}}\end{array}$ & $\begin{array}{l}5-42 \\
\text { Total }\end{array}$ & $\begin{array}{l}5-42 \\
\text { Free }\end{array}$ & $\begin{array}{l}5-36 \\
\text { Total }\end{array}$ \\
\hline ASPARTIC & 9.30 & 40.90 & 26.4 & 14.7 & 0.370 & n.d. & 0.530 & n.d. & 0.004 & $\operatorname{tr}$ & 0.19 \\
\hline THREONINE & 0.40 & 0.55 & 0.4 & - & 0.010 & n.d. & $\sim 0.001$ & n.d. & 0.004 & $\operatorname{tr}$ & 0.09 \\
\hline SERINE & 0.70 & 0.51 & 0.5 & 0.2 & 0.007 & n.d. & 0.60 & n.d. & 0.005 & 0.001 & 0.12 \\
\hline GLUTAMIC & 4.20 & 15.88 & 17.3 & 2.3 & 0.380 & n.d. & 0.450 & n.d. & 0.030 & 0.014 & 0.14 \\
\hline PROLINE & 2.30 & 7.53 & 8.4 & $\sim 5.5$ & n.d. & n.d. & n.d. & n.d. & $\operatorname{tr}$ & $\operatorname{tr}$ & n.d. \\
\hline GLYCINE & 5.90 & 16.67 & 16.3 & 5.9 & 0.700 & $\sim 7.40$ & 0.980 & 8.20 & 0.050 & 0.013 & 0.47 \\
\hline ALANINE & 5.80 & 18.99 & 24.0 & 13.7 & 2.400 & $\sim 25.40$ & 2.360 & $\sim 19.60$ & 0.028 & 0.008 & 0.31 \\
\hline$\alpha$-AMINO BUTYRIC & n.d. & 3.20 & $\sim 2.0$ & $\operatorname{tr}$ & $\operatorname{tr}$ & 3.50 & $\operatorname{tr}$ & 3.70 & - & - & - \\
\hline VALINE & 2.30 & 8.14 & 11.3 & 3.6 & 0.350 & 5.48 & 0.580 & 4.50 & 0.011 & $\operatorname{tr}$ & 0.16 \\
\hline METHIONINE & - & - & - & - & - & - & - & - & - & - & - \\
\hline ALLOISOLEUCINE & 0.28 & 2.54 & 3.9 & 1.6 & 0.030 & 1.55 & $\sim 0.030$ & 1.50 & 0.010 & $\operatorname{tr}$ & 0.04 \\
\hline ISOLEUCINE & 0.35 & 2.35 & 3.3 & 1.1 & $<0.030$ & 1.23 & $\sim 0.020$ & 1.09 & 0.008 & $\operatorname{tr}$ & 0.11 \\
\hline LEUCINE & 1.94 & 6.29 & 5.2 & 1.8 & 0.130 & 1.46 & 0.220 & 1.06 & 0.016 & $\operatorname{tr}$ & 0.14 \\
\hline TYROSINE & $0.27 ?$ & $1.87 ?$ & $?$ & $?$ & - & $?$ & $?$ & $?$ & $?$ & - & $?$ \\
\hline PHENYLALANINE & 0.82 & 2.84 & 1.9 & - & - & $?$ & $?$ & $?$ & $?$ & - & $?$ \\
\hline HISTIDINE & - & - & - & - & - & - & - & - & - & - & - \\
\hline$\gamma$-AMINO BUTYRIC & - & $1.16 ?$ & $\operatorname{tr}$ & $?$ & $?$ & 4.00 & - & 2.90 & - & - & - \\
\hline ORNITHINE & 0.70 & 1.07 & 0.8 & $?$ & - & 0.25 & - & $0.63 ?$ & $\operatorname{tr}$ & $\operatorname{tr}$ & 0.66 \\
\hline LYSINE & 0.65 & 1.20 & 1.0 & $?$ & - & 0.39 & - & $0.62 ?$ & $\operatorname{tr}$ & $\operatorname{tr}$ & 0.49 \\
\hline ARGININE & - & - & - & - & - & - & - & - & - & - & - \\
\hline TOTAL & 36.1 & 134.3 & 120.7 & 50.4 & 4.4 & $50.8+$ & 5.2 & $43.9+$ & 0.16 & $\sim 0.04$ & 2.92 \\
\hline alloiso/iso & 0.80 & 1.06 & 1.18 & 1.45 & $>1.0$ & 1.26 & $\sim 1.5$ & 1.34 & 1.25 & - & 0.36 \\
\hline
\end{tabular}

Note: $-=$ not detected; n.d. $=$ not determined $; \operatorname{tr}=$ trace $;=$ peak eluted in position of amino acid, questionable identity.

${ }^{a}$ These samples were separated from clay minerals by centrifugation before hydrolysis (total only) and desalting. Weights of the other 6-47-2 samples were known only approximately; within experimental error, it appears that the free amino acids $=$ total amino acids in Sample 6-47-2. 